\title{
Factors Affecting Farm Succession and Occupational Choices of Nominated Farm Successors in Gilgit-Baltistan, Pakistan
}

\author{
Muhammad Abid Shahzad ${ }^{1}$, Syed Abubakr ${ }^{2}$ and Christian Fischer ${ }^{1, *(D)}$ \\ 1 Faculty of Science and Technology, Free University of Bozen-Bolzano, 39100 Bolzano, Italy; \\ mshahzad@unibz.it \\ 2 Department of Agriculture and Agribusiness Management, University of Karachi, Karachi 75270, Pakistan; \\ syedabubakr78@gmail.com \\ * Correspondence: christian.fischer@unibz.it
}

Citation: Shahzad, M.A.; Abubakr, S.; Fischer, C. Factors Affecting Farm Succession and Occupational Choices of Nominated Farm Successors in Gilgit-Baltistan, Pakistan. Agriculture 2021, 11, 1203. https://doi.org/ 10.3390 /agriculture11121203

Academic Editor: Gioacchino Pappalardo

Received: 22 October 2021

Accepted: 17 November 2021

Published: 29 November 2021

Publisher's Note: MDPI stays neutral with regard to jurisdictional claims in published maps and institutional affiliations.

Copyright: (c) 2021 by the authors. Licensee MDPI, Basel, Switzerland. This article is an open access article distributed under the terms and conditions of the Creative Commons Attribution (CC BY) license (https:// creativecommons.org/licenses/by/ $4.0 /)$.

\begin{abstract}
Mountain farming communities in Pakistan are exhibiting an increased rate of rural-tourban migration and a rapid growth in the non-farm sector, which has threatened the sustenance of agricultural activity. This study examined the determinants of farm succession using a logit regression model and employed a multinomial logit regression model to study the factors influencing the future occupational choices of the potential farm successors. The study was based on quantitative survey data obtained from 421 farm managers and 155 potential farm successors and qualitative data from 12 key informants from two different districts in Gilgit-Baltistan. The survey results show that around $67 \%$ of the farmers had a potential successor. Farm succession was mainly explained by farmer characteristics (e.g., farmer age, gender and education), farm characteristics (e.g., farm size, specialization in horticulture, etc.) and agricultural income. Regarding the occupational choices, part-time farming $(66 \%)$ was the most commonly reported choice. The results indicate that it was mainly farm successors' personal characteristics (such as age, education and marital status) and agricultural income that led to the choices "undecided" and "exit", whilst farm characteristics (e.g., farm size) and the main farm operators' non-farm activity were significantly associated with the choice "part-time". Policies aimed at improving the local income situation and investments in skill-building and infrastructure development can assist in farm sustenance.
\end{abstract}

Keywords: farm succession; occupational choice; mountain farming; Gilgit-Baltistan; Pakistan

\section{Introduction}

With increased rural outmigration, agricultural abandonment and the aging of the farming population, the sustenance of the agricultural economy is increasingly at risk $[1,2]$, particularly in mountain areas. The maintenance of farming activities in the mountains is important not only for the livelihoods of local communities but also for protecting and preserving the landscape, preventing environmental degradation and ensuring food security [3].

One element of agricultural sustainability is the ability to find a successor to take over the family farm. In disadvantaged areas, such as mountains, most farms are familyoperated. In such farms, it is highly unlikely for farming activity to be taken over by someone outside the farm household. First, farm takeover by an outsider would entail high investments and the use of hired labor with very low profit margins expected. This would increase the likelihood of farm abandonment. Second, such a farm transfer would imply the loss of the farm-specific, experience-based knowledge and expertise accumulated within the household [4]. This is why intergenerational farm transfer is often a necessary condition for farm survival, particularly in mountain areas [5].

The economic development of the rural mountainous regions of Gilgit-Baltistan (GB), Pakistan, should be seen in the context of the geographic and economic peculiarities of the region and the numerous constraints on growth. The region is marked by rugged 
terrain, lower population density (12 people per square kilometer-30 times lower than that of Punjab province [6]) and constraints such as subsistence farming, environmental and climatic limitations, higher production costs and lack of infrastructure and market access. Given these characteristics, it is not surprising that the region has historically lagged behind the rest of Pakistan [7]. Still, a structural transformation appears to be underway. There has been a steady shift from subsistence farming to cash crops and fruit production, which is particularly noticeable in the accessible parts of the region that are located closer to urban centers. In addition, the rising proportion of household income from non-farm activities (increasing from $43 \%$ in 1994 to $63 \%$ in 2005 [6] and more than $70 \%$ in 2020 [8]) plays an important role in the transformation of the rural economy. Similarly, the increased labor outmigration towards the services sector in down-country Pakistan stemming from the improved formal education systems has increased the share of non-farm employment. In 2001, about $24 \%$ of men (aged 18 and above) were employed outside rural GB, compared to the $15 \%$ migration rate among the same group across all of rural Pakistan [6]. The share of migrant workers and outmigration from GB is much higher. Although updated statistical evidence is scarce, different studies nevertheless point to a gradual increase in outmigration over time. From the perspective of food security, according to a report by the World Bank, four out of five districts in GB are "extremely insecure" and the remaining district, Gilgit, is "very insecure" [6].

Under these circumstances, the maintenance of farming communities in GB is largely under threat. The increased rate of rural-to-urban migration $[9,10]$, particularly that of younger people [11] and the rapid growth of the non-farm sector $[8,9]$ have resulted in decreased agricultural land-use and increased uncertainty regarding farm continuation [12]. The concerns regarding farm survival due to the unavailability of young successors are also reported in other parts of the world [5,13,14]. Gasson et al. [15] termed this phenomenon the "inheritance dilemma". In some regions, the lower rates of farm succession are linked to rural depopulation $[16,17]$, especially in marginal and disadvantaged areas where agriculture is essential to the maintenance of the rural population. Although intergenerational farm succession remains the main driver of farm survival in GB, in the context of recent developments, the situation merits a timely investigation. The current study sought to determine whether or not the potential farm successors could be identified in the study area, how they intended to move forward in their occupation and what the opinion of locals was on this issue.

Therefore, the main objective of this study was to identify the determinants of farm succession by investigating, in particular, how different farmer and farm characteristics affect the presence of a farm successor. A further aim was to deepen our understanding of the future outlook of the agricultural system and study the factors underlying the future intentions of farm successors, i.e., determine whether the farm successors would continue full-time or part-time, whether they would exit or whether they were undecided by means of quantitative analysis. In addition, in order to better understand farmers' opinions on the issue, we present some qualitative group discussion responses. This study builds on similar research in other localities by providing insights into the issue of farm succession in disadvantaged farming communities. Such an understanding is key to evaluating the on-ground situation in GB, and we use it to derive specific policy recommendations.

In the following sections we provide a brief review of the relevant literature, discuss the methodology adopted and the results, including qualitative and quantitative analyses, and finally offer some conclusions with relevant policy considerations.

\section{Literature Review}

Succession is defined as relocating all the managerial control and the ownership of the land as well as the assets belonging to the family farm business among the younger farm successors [18]. It is a continuous process that begins with the early involvement of the potential successor in farming activities. The successor becomes a vital member of the farm household as his interests grow and responsibilities on the farm increase. 
Chiswell [2] divided the process of succession into four different stages: "socialization", "technical apprenticeship", "partnership" and finally "controller". This gradual transfer of the managerial and operational control of the farm between generations has long been regarded as a crucial and often challenging phase, with implications for both individual farming entities and the long-term viability of family farming systems [2,19].

The issue of farm succession has been examined from a variety of perspectives. Farm succession, for example, is linked to agricultural maintenance and the aging of the farming population based on existing evidence of a positive correlation between younger farmers and farm efficiency [20]. Another issue is land market disturbances, since reduced succession increases barriers to generational renewal, therefore causing disruptions in the entry-exit process of the farm labor force [21]. Some of the studies focused on the timing and intergenerational component of farm succession, while others studied the effects of agricultural policies on succession [22] or the impact of intrafamily succession on farm productivity $[23,24]$. Thus, the study area remains relevant from multiple viewpoints.

\subsection{Factors Affecting Farm Succession}

Previous studies identified various factors affecting family farm succession. They include readily observable farmer and farm characteristics, other external factors such as demographic trends, community attributes and geographical location and external factors such as regional and local policies.

Intergenerational farm succession is particularly affected by farmer characteristics. For instance, the age of the main farm operator is, in most cases, positively associated with the occurrence of succession $[14,25]$. The gender of the main farm manager has been found to yield mixed (positive and negative) effects [4,26-28]. The education of the farm managers also affects the succession process: higher educational attainment has been found to be connected with the perception of a greater valuation of farm continuity over farm abandonment [29]. Glauben et al. [30] found it to be linked with a delayed transfer of agricultural land ownership to a successor.

Several farm family variables are also considered to influence farm succession, among them the number of children of the main farmer [29,31], the farmer's spouse working on the farm [32] and the age of the potential successor [33]. Furthermore, the potential farm successor's age, education and his/her involvement in farming activities have also been found to affect farm succession $[27,29,34,35]$.

Various farm characteristics such as the degree of farm mechanization and capital accumulation have a positive impact on succession $[4,36,37]$. Previous studies have shown that in larger farms, it is easier to overcome financial constraints, thus reducing the restrictions to future farm expansion $[30,34]$. The factors related to location such as the distance of the farm from the nearest urban center have also been found to influence farm succession [33].

Finally, farms that benefit from governmental support such as subsidies have better chances to sustain their existence [38]. Similarly, having a supplemental income from off-farm opportunities (such as non-agricultural jobs or businesses) also help in financing agricultural inputs, hence increasing the likelihood of farm survival. However, the evidence on the impact of off-farm labor on farm continuity is puzzling: a negative link has been found by Stiglbauer and Weiss [26], and a positive one by Corsi [4].

\subsection{Factors Affecting the Occupational Choice of Farm Successors}

With a few exceptions, the studies explicitly focusing on factors influencing the occupational choices of farm successors (i.e., to continue farming full-time, part-time, or not working) are scarce [32]. In the following, the decision of a potential successor to pursue farming or a non-farming occupation is mainly studied from the perspective of the occupational choice theory.

The choice is dependent on various factors, mainly including different farm and farmer characteristics. Many studies found that the level of education of potential farm successors has a negative effect on their decision to continue farming, i.e., the higher the 
educational level, the lower is the probability of farm succession [25,39]. The educational level of the main farm manager is also reported to affect the occupational choice of the farm successor. More highly educated farm managers are more likely to farm part-time, which also influences the next generation to continue part-time [27]. Likewise, farmers with larger landholdings have the incentive to expand and diversify farm businesses to obtain a better future income. Therefore, they encourage their successors to continue expanding farming enterprises $[25,27]$. The location of the farm also influences the choice of the farm successor [29]. Farms located near an urban center would have better access to non-farm opportunities, resulting in a higher tendency of the farm successor to farm part-time.

The literature also describes how socialization at the farm level acts as an incubator for the process of farm succession and influences successors' choices. Farmers' involvement in farming and skill-building at a younger age aids in emotional attachment toward farming, which results in a smoother transition, a reduction in transfer costs and lower transfer taxes $[2,34,40,41]$.

In mountain areas, the occupational choice of the farm successor has particular significance. The motivation to sustain a farming occupation is low in areas where farms are scattered, farming seasons are short, climatic conditions are extreme, land is scarce and farmers suffer from a lack of adequate inputs [42]. As a result, farmers incline towards additional off-farm income or entirely shift to a non-agricultural occupation. In such circumstances, the choice of young farmers is found to be especially dependent on the relative income they get from off-farm sources [43]. Factors such as farm solvency, future farming opportunities and long-term farm income are also important in determining the occupational choice of the future generation of farmers [44].

\section{Materials and Methods}

\subsection{Site Selection}

The present study was conducted in two districts from the GB region-Gilgit and Nagar. The locations included the Naltar Valley (Naltar Bala and Naltar Pain) in the district of Gilgit and Nagar-I and Nagar-II in the district of Nagar (Figure 1). The most important criteria used to determine the study areas were based on the variation in the communities' dependence on natural resources, an adequate environmental variability, the agricultural importance and the diversity in the socio-economic profile of the area.
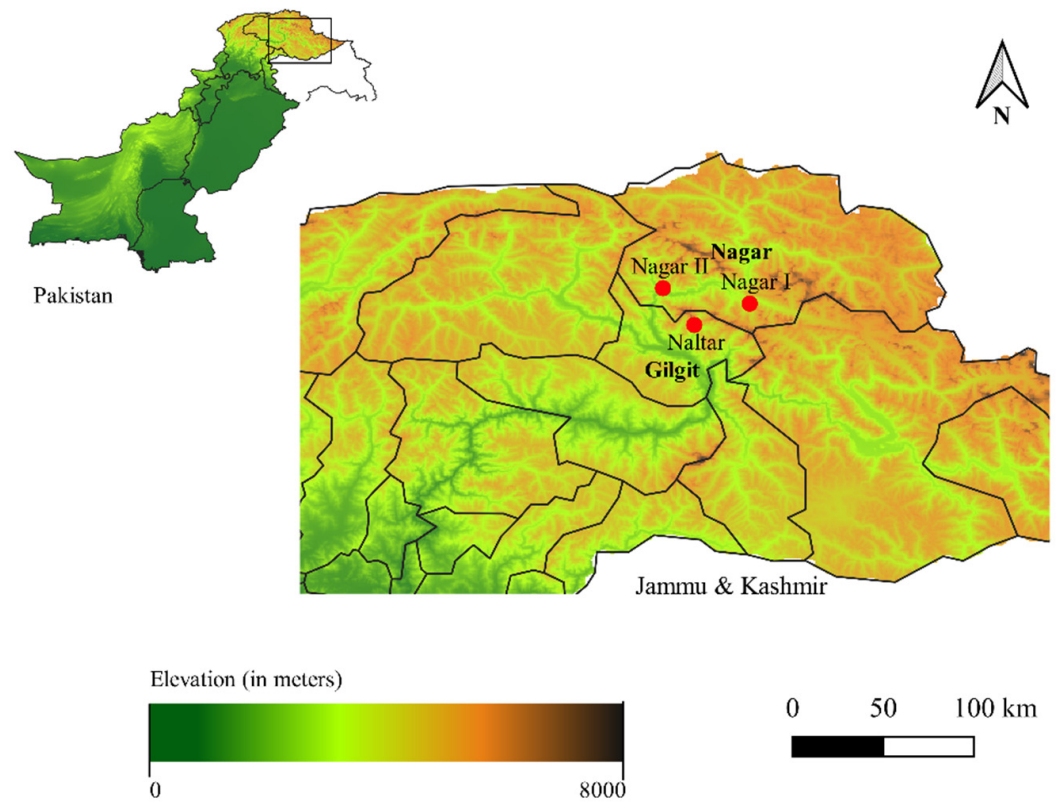

Figure 1. Study area location in Gilgit-Baltistan (GB), Pakistan, and the altitudinal profile of the region. The villages selected for surveying are marked in red. 
The Naltar Valley is located within the Himalayan Highlands, northwest of the Karakorum Mountain range, which is about $40 \mathrm{~km}$ from the main Gilgit town. The valley starts with a narrow, steep area beginning from the river of Hunza and stretches significantly with the elevation. The altitude ranges between 1700 and $5000 \mathrm{~m}$, ending in the Naltar Pass. The valley falls into the Montane Dry Temperate Coniferous Zone of the Pakistan Forest Classification. Its climate is dry temperate, considering severe and lengthy winters and short but pleasant summers. According to the 2017 Population Census, the total population of the Gilgit district is 285,236 , the average number of livestock units per capita is 1.70 and the average per capita agricultural landholding size is 0.02 hectares [45]. The Naltar Valley in the Gilgit district is populated by about 6000 inhabitants in 750 households. The livelihoods of the people are mainly dependent on agricultural income (mainly horticulture and livestock) and off-farm income (mainly from non-agricultural businesses, government and private jobs, pensions and daily wages).

The district of Nagar is situated in a semiarid mountain valley in the western part of the Karakoram, bordering Hunza to the north and Gilgit to the south. For centuries, Nagar was a princely state governed by an autocratic ruler (tham) and a small local elite. The people lived in relative isolation for centuries. Later, in 1972, the government of Pakistan resolved the princely state and formally integrated it into the political system. The region has undergone major developments following subsequent reforms and the completion of the Karakoram Highway.

Several high peaks of $>7000 \mathrm{~m}$ (such as Rakaposhi, Diran peak, etc.), which are popular among trekkers and mountaineering communities, are located in the surroundings of Nagar Valley. The Nagar district is particularly known for its touristic value. The total population of the Nagar district is 71,746 , the average number of livestock units per capita is 1.70 and the average per capita agricultural landholding size is 0.03 hectares [45]. From Nagar I and Nagar II, the villages of Hopar valley, Ghulmet and Thole also comprise about 6000 inhabitants. From the agricultural point of view, it is also considered as one of the important districts in GB for its horticultural and livestock production. It has a combined irrigated crop farming system. Livestock makes use of high pastures during the summer months. The main field crops are wheat, potatoes, maize, alfalfa and buckwheat. However, the reliance on traditional agriculture is decreasing, and farmers are shifting to high-value horticultural crops [46] such as apricots, cherries and apples.

\subsection{Sampling}

Primary data were collected in the localities from January to March 2020. Within each locality, approximately $14 \%$ of the households were surveyed. The farm households were selected using a mixed stratified and random sampling technique, which ensured a diverse range of socio-economic profiles was included and led to a better response rate during the household surveying process. The households were chosen from the list of farmers in each locality provided by the local agricultural research department. Only households in which the main farm manager was aged over 45 years were chosen. All the potential respondents were contacted to ask for consent prior to the survey and were informed of the motives, which first helped in planning the survey and then ensured the presence of all the required persons (i.e., the main farm manager/owner and the potential successor) at the time of interview. The survey team was accompanied by local research assistants assigned by the department of agricultural research of GB who interpreted the questions orally where the respondent did not speak Urdu (the national language of Pakistan). The community values and cultural hospitality helped significantly in meeting the goals of the survey within the designated time. Furthermore, the female farmers were interviewed by a team consisting of women research assistants. This resulted in a high response rate and a more efficient interviewing. The overall final response rate was above $90 \%$. 


\subsection{Survey Methods and Questionnaire}

To identify the factors influencing intergenerational farm succession and the occupational choice of nominated farm successors on family farms, the current qualitative and quantitative study collected information from key informants, owners/managers of family farms and potential farm successors.

As the first step, to gather descriptive information regarding the generational continuity and sustenance of farms, the future choices of young farmers and a better understanding of farmers' perspectives, key informant interviews were conducted. A key informant interview is an efficient technique to obtain information from the target population. This method is especially useful when the primary purpose of the study is to generate suggestions and recommendations and quantitative data collected through other methods need interpretation [47].

Key Informant Interviews: First, the key informant interviews were conducted to gather qualitative responses. A total of 12 farmer representatives including heads of the local support organization, village headmen (locally called numberdar) and sub-headmen (locally called moutaber) and some informed and educated farmers including successors from all study areas were chosen as the key informants. These discussions were conducted in small groups.

Questionnaire Survey: The other important method of data collection used in the study was the farm household survey. Household surveying is an appropriate and commonly used method to gather demographic data [48]. The unit of the analysis is the farm manager, the main caretaker and decision-maker at the farm and the potential successor (if present) who is going to take over the farm.

The study is based on data collected through a questionnaire from 220 farm managers and 155 potential farm successors. To rectify inconsistencies and obtain suggestions to improve the questionnaire, a pre-testing session was conducted with the key informants. The final version of the questionnaire consisted of a mix of open-ended and close-ended questions. The questionnaire content mainly covered farm and farmer characteristics, information regarding family and livelihood, questions regarding potential successors' future choices and other individual characteristics, community characteristics, variables affecting the choice of farm successors and farmers' opinions on generational continuity.

\subsection{Statistical Analysis}

In this study, both qualitative and quantitative methods were employed to analyze the data. First, we provide qualitative analysis regarding the generational continuity and sustenance of farming activities and the future choices of farm successors in the mountainous rural regions of GB, Pakistan. This included the perspective of key informants, current farm managers and farm successors. The qualitative information was used to understand the underlying perspectives affecting the farming sector in the region.

Then, for quantitative analysis, we first estimated a logit model to determine the impact of factors influencing the probability of intergenerational farm succession. We asked the main farm manager if the farm has a potential successor or not. Since the dependent variable in this model is dichotomous, i.e.,

$$
Y_{i}=\left\{\begin{array}{l}
1 \text { if the farm has a potential farm successor } \\
0 \text { otherwise }
\end{array}\right.
$$

we assumed a logit model to be an appropriate choice. The logit is defined as the natural logarithmic value of the odds in favor of a positive response (in this case having a potential farm successor). The mathematical representation of the model is given by:

$$
\log \left(\frac{P_{i}}{1-P_{i}}\right)=X_{i} \beta+\Psi_{i}
$$


where $X_{i}$ is a vector of explanatory variables, $P_{i}$ is the probability that the $i$ th farm has a potential farm successor, $\beta$ is a vector of unknown parameters and a residual error term assumed normally distributed with a zero mean and constant variance. This model allows us to quantify whether and to what extent various characteristics of a family farm and its owner family, along with other explanatory variables, affect the probability of farm succession in the study areas.

To deepen our understanding of the future outlook of the farming sector in northern Pakistan, we further modeled the occupational choices of the potential farm successors and estimated a multinomial logit model. The potential farm successors were asked "How do you intend to operate your farm in the future?", to which the responses were divided into four categories. First, full-time farming; second, a non-farming occupation combined with farming; third, exiting farming occupation; and finally, undecided, if the respondent had not yet decided.

It is assumed that the farm successors have a subjective evaluation of each occupational choice, as a utility index [32]. An individual chooses a certain occupation if this index is greater than that for every other occupational choice that can be chosen. In the multinomial logit model, $x_{i}$ denotes the explanatory variables that influence the utility associated with each occupational choice $j$ as perceived by each farm successor $i$. The probability that the successor $i$ will choose occupation $j$ is:

$$
\operatorname{Prob}(i \text { chooses } j)=\frac{\exp \left(\beta x_{i j}\right)}{\sum_{k=1}^{m} \exp \left(\beta x_{i k}\right)}
$$

\section{Results and Discussion}

\subsection{Descriptive Information on Family Farm Succession}

Around $67 \%$ of the farmers stated that their farm has a potential successor. In some cases, there were more than one potential successors, which is a norm in the region, as farms are often owned and operated by a joint family. Over $59 \%$ of the farmers have a potential successor aged 55 and over. Regarding education, the farm managers with a successor have attended a higher number of agricultural training (2.75) and attained a higher number of years of education (9.2) than their counterparts. Among the farmers with successors, around $80 \%$ are involved in other gainful activities, with an average agricultural income of about 100,000 Pakistani rupees, which is almost $25 \%$ higher than the agricultural income of farms without a successor. Furthermore, farmers with a successor have relatively larger landholdings and a greater number of livestock units, and they employ a lower number of hired labor. Around $36 \%$ of all farmers are specialized in horticultural crops, of which the share of farmers with a farm successor is $46 \%$.

Regarding family characteristics, farms where farmer spouses also participate in agricultural activities share a slightly higher percentage of farm successors and have a slightly lower number of total household members than the farms without a successor. Most of these farmers (63\%) have at least one of their children actively participating in farm operations.

Farm managers were asked to evaluate the development of their farm in the last 24 months and rate their progress from 'declined significantly' to 'improved significantly' on a scale of 1 to 5 . Noticeably, more than $46 \%$ of the farm managers with a potential successor believe that their farm has improved, while $34 \%$ believe that it remained steady in the last 2 years. Farmers, in an attempt to assist a smooth farm transfer and ensure sustainable economic growth, make developmental changes on their farms (such as farm expansion, setting up diversification, increasing the number of livestock, etc.). We asked the farm managers if there were any development activities made on the farm in the last 5 years, particularly changes in the production scale or farm type. In response, $61 \%$ of the farmers with a farm successor answered in the affirmative to making changes on their farms. 
Regarding the indicated future occupational choices by farm successors, out of the total 133 statements, part-time farming was the most common occupational choice, as reported by $66 \%$ of the farm successors. Whereas more than $11 \%$ reported full-time farming, $9 \%$ showed an intention to exit farming, and $14 \%$ were still undecided. On average, farm successors were 24 years old. The average of farm successors' age by occupational choice $1-4$, remained as 28, 24, 23 and 21, respectively. The successors with schooling levels of illiterate, up to 6 years, 8 years, 10 years, 12 years and university graduated, accounted for 7 , $11,11,30,30$ and $20 \%$ of the sample, respectively. Around $36 \%$ of farm successors marking 'part-time farming' as their choice have 12 years of educational experience. More than $66 \%$ of potential successors planning to exit farming are university graduates. Regarding marital status, about $55 \%$ of all farm successors are married. Of all married farm successors, $71 \%$ marked part-time farming as their choice, while $20 \%$ of undecided successors are unmarried. A detailed summary of the statistics is given in Table 1.

\subsection{Qualitative Responses to Generational Continuity on Farms}

Out of the total 12 key informants, 10 were available for a discussion regarding the generational continuity of farms and the choice of young farmers to continue farming.

The respondents indicated that it is mainly the size and economic situation of the farm that influence the continuity of the agricultural activity. One of the respondents explained it as below:

"The better the economic situation of the farm, the higher is the chance for it to sustain and continue. This is why farmers, especially in Nagar, are taking steps to improve agricultural productivity to sustain farming activities (particularly by setting up homebased processing plants, involvement in agritourism and moving towards the cultivation of high-value crops)".

Furthermore, the degree of affinity of the potential successor with the farm and farming activity (i.e., participation in farming operations, a degree in agriculture/attendance in agricultural training, personal interest, etc.) is also quoted as an important factor. Regarding the return of the younger generation of farmers to farming activity, the respondents mainly believed that it is probable that at some point in their lives, farmers will continue their forefathers' legacy and return to the farming profession, this being especially true of youngsters that migrate from rural to urban areas without their families. This also relates to the gender of the potential successor, as most of the migrating youngsters are males leaving behind their female counterparts to continue the farming business. One of the key informants described his opinion as:

"Many youngsters who decided to move towards bigger cities (such as Islamabad, Lahore and Karachi) to find job opportunities might not make a return to their family farms. Even in the case of their return, it is highly unlikely that they would involve in farming as their main occupation. On the other hand, those who stayed close to the farming occupation are perhaps the next generation of farmers."

The role of the main farm manager is also characterized as a crucial factor. The intra-family discussions regarding succession, planning on the improvement of the farm infrastructure, encouraging the potential successor to stay on the farm, etc., are also termed as equally important factors in facilitating farm succession. A female key informant voiced her opinion as:

"... when we sit together and discuss our issues with each other, there are farmers who express their concerns over the disinterest of their children in continuing farming. However, it is also true that many of the farmers do not even involve their children in family discussions and do not make deliberate efforts to encourage them to continue to engage in agriculture as their profession. As a consequence, they see their children drift away from farming." 
Table 1. Details of variables used in the regression models.

\begin{tabular}{|c|c|c|c|}
\hline Variable & Description & Mean & SD \\
\hline \multicolumn{4}{|l|}{ Dependent variables } \\
\hline Farm succession & $\begin{array}{l}=1 \text { if the farm has a farm successor, } 0 \\
\text { otherwise }\end{array}$ & 0.68 & 0.47 \\
\hline $\begin{array}{l}\text { Occupational choice of farm } \\
\text { successor }\end{array}$ & $\begin{array}{l}=1 \text { if successor choose full-time farming, } \\
=2 \text { if part-time },=3 \text { if exit farming and }=4 \\
\text { if } s / \text { he is undecided }\end{array}$ & 2.24 & 0.84 \\
\hline \multicolumn{4}{|l|}{ Farmer characteristics } \\
\hline Gender & $=1$ if farmer is male, 0 otherwise & 0.65 & 0.48 \\
\hline Age of main farm manager & Number of years of age & 52.6 & 6.56 \\
\hline Age of farm successor & $\begin{array}{l}\text { Number of years of age } \\
=0 \text { if the farmer is illiterate, }=1 \text { if has }\end{array}$ & 24.1 & 5.68 \\
\hline $\begin{array}{l}\text { Education of main farm } \\
\text { manager }\end{array}$ & $\begin{array}{l}\text { schooling up to } 6 \text { years, }=2 \text { if } 8 \text { years, }=3 \\
\text { if } 10 \text { years, }=4 \text { if } 12 \text { years and }=5 \text { if } \\
\text { university graduated or more }\end{array}$ & 2.62 & 1.32 \\
\hline Education of farm successor & $\begin{array}{l}=0 \text { if the farmer is illiterate, }=1 \text { if has } \\
\text { schooling up to } 6 \text { years, }=2 \text { if } 8 \text { years, }=3 \\
\text { if } 10 \text { years, }=4 \text { if } 12 \text { years and }=5 \text { if } \\
\text { university graduated or more }\end{array}$ & 3.36 & 1.88 \\
\hline Farm successor marital status & $\begin{array}{l}=1 \text { if the farm successor is married, } 0 \\
\text { otherwise }\end{array}$ & 0.55 & 0.50 \\
\hline Spouse on farm & $\begin{array}{l}=1 \text { if the farmer's spouse work on farm, } \\
0 \text { otherwise }\end{array}$ & 0.83 & 0.38 \\
\hline Trainings & $\begin{array}{l}\text { Number of agricultural trainings } \\
\text { attended }\end{array}$ & 2.29 & 2.22 \\
\hline \multicolumn{4}{|l|}{ Farm characteristics } \\
\hline Land owned & $\begin{array}{l}\text { Total land owned by the farmer in kanals } \\
\text { (1 hectare }=19.8 \text { kanals) }\end{array}$ & 11.7 & 11.1 \\
\hline Livestock units & Total number of livestock units owned & 6.66 & 14.78 \\
\hline Hired workers & $\begin{array}{l}\text { Total number of hired workers on the } \\
\text { farm }\end{array}$ & 1.20 & 1.78 \\
\hline Total household members & Total number of household members & 8.79 & 4.08 \\
\hline Agricultural income & $\begin{array}{l}\text { Total agricultural income in the previous } \\
\text { year in Pakistani rupees }(000 \mathrm{~s})\end{array}$ & 79.4 & 86.5 \\
\hline Off-farm work & $\begin{array}{l}=1 \text { if farmer is involved in off-farm } \\
\text { work, } 0 \text { otherwise }\end{array}$ & 0.71 & 0.45 \\
\hline Farm diversification & $\begin{array}{l}=1 \text { if farmer is involved in farm } \\
\text { diversification, } 0 \text { otherwise }\end{array}$ & 0.38 & 0.49 \\
\hline Farm altitude & The altitude of the farm in meters. & 2272 & 765 \\
\hline Specialist horticulture & $\begin{array}{l}=1 \text { if farm specializes in horticulture, } 0 \\
\text { otherwise }\end{array}$ & 0.43 & 0.50 \\
\hline \multicolumn{4}{|l|}{ Others } \\
\hline Changes on farm & $\begin{array}{l}=1 \text { if the farmer has made changes in } \\
\text { farm production in the last } 5 \text { years, } 0 \\
\text { otherwise }\end{array}$ & 0.52 & 0.50 \\
\hline Farm evaluation & $\begin{array}{l}=1 \text { if farmer evaluates the development } \\
\text { of his farm during last } 24 \text { months as } \\
\text { declined significantly; }=2 \text { if declined } \\
\text { somewhat; }=3 \text { if remained the same; }=4 \\
\text { if improved somewhat; }=5 \text { if improved } \\
\text { significantly }\end{array}$ & 3.06 & 1.28 \\
\hline Successor participation & $\begin{array}{l}=1 \text { if the potential farm successor } \\
\text { participates in farming activities, } 0 \\
\text { otherwise }\end{array}$ & 0.49 & 0.50 \\
\hline
\end{tabular}


The Perspective of the Current Farm Manager: We then asked the primary farm operators: "How do you see the situation of farm succession at your farm?", to which farmers gave a variety of responses.

Many farmers witha nominated farm successor responded with an explanation of the deliberate efforts and steps they have taken to encourage them to pursue farming. The efforts to expand farm businesses are either already in place or are in the process of planning to create opportunities for the next generation.

Farmers mainly associated the following rationale for farm continuation: "farming is our way of life", "farming is now more suitable for youngsters as it is evolving into modern business ventures", "farming is crucial for the livelihood in these valleys", etc. Issues concerning the economic sustainability of farming and climate change effects were also the center of farmers' opinion on the topic.

Several farmers who are pursuing growth and expansion through diversification activities and new income streams reported to have their farm successors actively engaged with the farm. On such farms, the young farmers are seen devoting most of their time to diversification activities. Talking to the research team, the village head explained:

"This is the peculiarity of the mountain region that you cannot survive merely on farm income unless you own a large and diverse agricultural business. Therefore, I along with my spouse mainly look after the farm while our children take care of the farm accommodation and organize tours during the tourism season. Our children must be involved in farming since they will be the future managers. I believe our farm will stay and the children will continue our legacy."

Farmers who do not yet have a potential successor expressed discontent with farm income and the future of farming as well as their belief that a non-farm career is a better option for their children. Although a considerable number of these farmers want their children to pursue farming as their profession, their children are not interested in taking over the farm business, at least not as their main occupation.

Farms located near high mountains and unfavorable locations are the least attractive. Here, rural households largely depend on tourism, transport and other non-farm businesses. The continuity of farms located in such places is mainly linked with cultural aspects. A part-time farmer expressed his concerns as follows:

"Domestic consumption is the focus of agriculture in Naltar Bala (upper Naltar). The majority of the people in this part of the valley survive on incomes from non-agricultural sources. I would not want my children to abandon our farm and I prefered to see them working in the government sector where they could earn higher income and lead a financially stable life".

The Perspective of Farm Successors: Although farm families in the region have been in the farming business for generations, there is no unanimity to the future aspirations of young farmers. This could be owing to differences in each farm family's socio-economic profile and financial circumstances, or to constantly changing external factors affecting the choices of potential successors. Nevertheless, upon asking "How do you see your commitment to farming in the future?", the respondents mainly indicated a plan to maintain an additional income channel either from farm diversification or off-farm activities. Most of these respondents stated that involvement in such activities is necessary because they are exposed to financial vulnerabilities stemming from climatic and economic factors. Some of the potential successors indicated a motivation to invest their time in farm-related diversification activities rather than looking for jobs in non-agricultural sectors. At the same time, many of them see their actual potential in tourism and other non-farm sectors. Nevertheless, several young farmers were optimistic and believed that with the public and private interventions in agribusiness development, the mountain farming sector can reach its actual potential. 
On the other hand, the responses indicating farming as an unattractive occupation to pursue as a full-time job included: "farm income is insufficient", "lack of access to inputs", "scarce land resources", etc.

Another key factor influencing farm continuity is the impact of family issues and the nature of the relationship between the successors and their parents. A few young farmers mentioned that even after the farm take-over, they have no or limited authority to make major decisions and gain operational control. The main farm manager continues to support the successor and actively engages in farming even years after retirement. A father-son duo is the most practical farming system available to new entrants wishing to farm. This could also contribute to disinterest in farming or at least to a lack of innovations within farming. A young farmer expressed his opinion as:

"I do not see my father retiring for a foreseeable future. He does not prefer to sit around.

The discussions over the transfer of major operational control are not relevant yet, but when I would take control, I would most likely rent out a part of our land to other people to be able to start other non-agricultural ventures".

\subsection{Results from the Farm Succession Model}

Table 2 presents the results of the econometric analysis, which identified the factors influencing farm succession. The parameter estimates of the logistic regression specify the direction of the impact and the level of significance, while the marginal effects quantify the change in the probability that farm succession will take place as a result of a change in the explanatory variable.

Table 2. Results of the logit model estimations of farm succession and their marginal effects.

\begin{tabular}{|c|c|c|c|c|}
\hline Variables & Coefficient & $\begin{array}{c}\text { Standard } \\
\text { Error }\end{array}$ & $\begin{array}{l}\text { Marginal } \\
\text { Effects }\end{array}$ & $\begin{array}{l}\text { Standard } \\
\text { Error }\end{array}$ \\
\hline \multicolumn{5}{|l|}{$\begin{array}{l}\text { Farmer characteristics } \\
\text { (main farmer) }\end{array}$} \\
\hline Gender (male) & $-1.533^{* * *}$ & 0.571 & $-0.122 * * *$ & 0.042 \\
\hline Age & $0.151^{* * *}$ & 0.046 & $0.012 * * *$ & 0.003 \\
\hline Education & 0.261 & 0.205 & 0.021 & 0.016 \\
\hline Spouse working on farm & 1.149 & 0.710 & 0.091 & 0.055 \\
\hline Trainings attended & $0.296^{* *}$ & 0.140 & $0.025 * *$ & 0.011 \\
\hline \multicolumn{5}{|l|}{ Farm characteristics } \\
\hline Land owned & $0.123 *$ & 0.111 & $0.010 *$ & 0.009 \\
\hline Livestock units owned & -0.033 & 0.030 & -0.003 & 0.002 \\
\hline Number of hired workers & $-0.195 *$ & 0.141 & $-0.015 *$ & 0.011 \\
\hline Household members & 0.042 & 0.067 & 0.003 & 0.005 \\
\hline Agricultural income & $0.040^{* *}$ & 0.017 & $0.003^{* *}$ & 0.001 \\
\hline Off-farm work & 0.139 & 0.653 & 0.011 & 0.052 \\
\hline Farm diversification & $1.441^{* *}$ & 0.694 & $0.114^{* *}$ & 0.052 \\
\hline Farm ownership nature & 0.923 & 0.685 & 0.073 & 0.053 \\
\hline Farm altitude & 0.000 & 0.000 & 0.000 & 0.000 \\
\hline Specialist horticulture & $1.261^{* *}$ & 0.591 & $0.100 * *$ & 0.045 \\
\hline \multicolumn{5}{|l|}{ Others } \\
\hline Changes on farm & 0.554 & 0.549 & 0.044 & 0.043 \\
\hline $\begin{array}{l}\text { Evaluation in last } 24 \\
\text { months }\end{array}$ & $0.859^{* * *}$ & 0.244 & $0.068^{* * *}$ & 0.017 \\
\hline Successor participation & $1.342^{* *}$ & 0.570 & $0.106^{* *}$ & 0.043 \\
\hline Intercept & $-13.37^{* * *}$ & 2.971 & & \\
\hline$N$ & 218 & & & \\
\hline Pseudo- $R^{2}$ & 0.60 & & & \\
\hline
\end{tabular}


Farmer Characteristics: The results show that there are a few farmer characteristics that are important in determining farm succession. For example, farmer gender and age are significantly related to succession (at a 1\% level of significance). As most of the farms (65\%) are managed by male farmers, the significant impact of gender is plausible. Regarding age, as the main farm manager grows older, he/she will be more aware of choosing a successor to take over the farm. However, most farm managers continue to operate their farms even after retirement. The finding is in line with other studies [14,25]. Fischer and Burton, in their study, further asserted that policies promoting early retirement may allow early succession. However, the policies may be counterproductive in cases where a farm transfer requires the long-term socialization of a successor. Another important factor is the number of agricultural trainings the main farm manager has attended, which partly reflects the intention to continue farming. This indicates farmers' understanding of the need to specialize in agricultural operation and the tendency to improve farm productivity, which is considered vital for farm continuation [49]. The marginal effects show that the probability of succession increases by $2.5 \%$ if the number of agricultural trainings attended is increased by 1 unit.

Farm Characteristics are found to be another important determinant of farm succession. Considering farm size, the coefficient for total land owned is positively and significantly associated with farm succession. Larger farms may offer better prospects of providing sufficient income and supporting rural livelihoods. Marginal effects indicate that an increase in landholding by 1 kanal increases the likelihood of farm succession by $1 \%$. Similarly, the specialization in horticultural crops is found to be highly relevant in determining farm succession. The marginal effects show that the likelihood of succession increases by $10 \%$ if a farm is specialized in horticulture. This can be attributed to the increasing trend of the commercialization of high-value crops in the region. In the study area, farmers continue to expand their farms through setting up diversification activities, especially on horticultural farms, which is a strategy that assists farm continuity [8]. Likewise, the number of hired workers shows a negative and significant relationship with succession. This can be explained by the fact that most of the hired and seasonal labor is employed on such farms where the family labor is scarce [31]. This commonly happens on farms where most of the household members, especially younger ones, are fully employed off-farm and are unavailable to participate in farm operations, suggesting a lower probability of succession.

The variables pertaining to the income situation of the farm appear to be especially relevant. Agricultural income is positively associated with farm succession (at a 5\% level of significance). The marginal effects indicate that an increase of one thousand Pakistani Rupees in agricultural income would make farm succession $0.3 \%$ more likely. This effect, though small, is statistically significant. At the same time, the impact of involvement in farm diversification activities is also significant. This, in the context of the study area, is linked with higher income and long-term planning for farm survival, as described by Shahzad and Fischer [8]. The marginal effects show that if a farm is involved in other gainful activities, then the likelihood of succession increases by 11\%. A previous study by Shahzad and Fischer [8] demonstrated that most farms in the region, especially horticultural farms and farms located near touristic spots, set up diversification activities and thus continue to survive. Therefore, our finding of a positive relationship between other gainful activities and farm succession is plausible.

Other Factors: Variables such as farmers' evaluation of their farms' performance and potential farm successors' active participation in farming activities are also among the important determinants of farm succession. The results show that higher scores in the evaluation of previous year's progress on the farm are positively and significantly (at a $1 \%$ level of significance) linked with the likelihood of succession. Meanwhile, the marginal effects imply that if the potential farm successor actively participates in farming operations, the probability of farm succession increases by $11 \%$. 


\subsection{Results from the Occupational Choice Model}

The multinomial logit model identified the factors influencing farm successors' occupational choices. The estimated model is significant at the $1 \%$ level of significance as determined by the likelihood ratio test. The model takes full-time farming $(\mathrm{CHOICE}=1)$ as the reference category. The parameter estimates (Table 3) of the model indicate the direction of the impact and level of significance between the dependent and independent variables, while the marginal effects show the magnitude of the impact of each independent variable on the probability of individual choices.

Table 3. Results of the multinomial logit model estimating occupational choice of farm successor and their marginal effects.

\begin{tabular}{|c|c|c|c|c|c|c|}
\hline \multirow[b]{2}{*}{ Variables } & \multicolumn{2}{|c|}{ Choice 2 = Part-Time } & \multicolumn{2}{|c|}{ Choice $3=$ Exit } & \multicolumn{2}{|c|}{ Choice $4=$ Undecided } \\
\hline & Estimates & $\begin{array}{l}\text { Marginal } \\
\text { Effects }\end{array}$ & Estimates & $\begin{array}{l}\text { Marginal } \\
\text { Effects }\end{array}$ & Estimates & $\begin{array}{l}\text { Marginal } \\
\text { Effects }\end{array}$ \\
\hline \multicolumn{7}{|l|}{$\begin{array}{l}\text { Farmer } \\
\text { characteristics } \\
\text { (successor) }\end{array}$} \\
\hline Age & $\begin{array}{l}-0.123 \\
(0.078)\end{array}$ & $\begin{array}{l}-0.002 \\
(0.009)\end{array}$ & $\begin{array}{l}0.034 \\
(0.163)\end{array}$ & $\begin{array}{l}0.006 \\
(0.005)\end{array}$ & $\begin{array}{l}-0.213 \text { * } \\
(0.114)\end{array}$ & $\begin{array}{l}-0.011 \text { * } \\
(0.008)\end{array}$ \\
\hline Education & $\begin{array}{l}0.016 \\
(0.326)\end{array}$ & $\begin{array}{l}0.036 \\
(0.034)\end{array}$ & $\begin{array}{l}1.657 * * \\
(0.905)\end{array}$ & $\begin{array}{l}0.056^{* *} \\
(0.025)\end{array}$ & $\begin{array}{l}0.037 \\
(0.427)\end{array}$ & $\begin{array}{l}0.018 \\
(0.028)\end{array}$ \\
\hline $\begin{array}{l}\text { Marital status } \\
\text { (married) }\end{array}$ & $\begin{array}{l}1.247 \\
(1.124)\end{array}$ & $\begin{array}{l}0.210 \\
(0.090)\end{array}$ & $\begin{array}{l}-3.163^{* *} \\
(2.350)\end{array}$ & $\begin{array}{l}-0.141^{* *} \\
(0.060)\end{array}$ & $\begin{array}{l}-0.526 \\
(1.316)\end{array}$ & $\begin{array}{l}-0.011 \\
(0.068)\end{array}$ \\
\hline \multicolumn{7}{|l|}{$\begin{array}{l}\text { Farm } \\
\text { characteristics }\end{array}$} \\
\hline Land owned & $\begin{array}{l}-0.101 * * \\
(0.061)\end{array}$ & $\begin{array}{l}-0.014^{* * *} \\
(0.017)\end{array}$ & $\begin{array}{l}-0.827 \\
(0.639)\end{array}$ & $\begin{array}{l}-0.024 \\
(0.021)\end{array}$ & $\begin{array}{l}-0.143 \\
(0.122)\end{array}$ & $\begin{array}{l}-0.005 \\
(0.013)\end{array}$ \\
\hline Off-farm work & $\begin{array}{l}2.357^{* *} \\
(0.976)\end{array}$ & $\begin{array}{l}0.048^{* *} \\
(0.092)\end{array}$ & $\begin{array}{l}2.895 \\
(1.967)\end{array}$ & $\begin{array}{l}0.011 \\
(0.057)\end{array}$ & $\begin{array}{l}2.949 \\
(1.238)\end{array}$ & $\begin{array}{l}0.059 \\
(0.076)\end{array}$ \\
\hline $\begin{array}{l}\text { Farm } \\
\text { diversification } \\
\text { Specialist } \\
\text { horticulture } \\
\text { Agricultural } \\
\text { income }\end{array}$ & $\begin{array}{l}0.374^{* *} \\
(1.196) \\
-0.148 \\
(1.266) \\
-0.003 * \\
(0.006)\end{array}$ & $\begin{array}{l}0.245 * * \\
(0.104) \\
-0.122 \\
(0.108) \\
-0.000 * \\
(0.002)\end{array}$ & $\begin{array}{l}-4.336^{*} \\
(2.468) \\
-0.533 \\
(2.262) \\
-0.006^{*} \\
(0.061)\end{array}$ & $\begin{array}{l}-0.108 * \\
(0.068) \\
-0.032 \\
(0.062) \\
-0.000 * \\
(0.002)\end{array}$ & $\begin{array}{l}-2.552 \text { ** } \\
(1.480) \\
1.364^{*} \\
(1.520) \\
0.001 \\
(0.011)\end{array}$ & $\begin{array}{l}-0.164 \text { ** } \\
(0.082) \\
0.152 * \\
(0.083) \\
0.000 \\
(0.001)\end{array}$ \\
\hline \multicolumn{7}{|l|}{ Others } \\
\hline $\begin{array}{l}\text { Successor } \\
\text { participation }\end{array}$ & $\begin{array}{l}-2.494 * \\
(1.375)\end{array}$ & $\begin{array}{l}-0.003 * \\
(0.085)\end{array}$ & $\begin{array}{l}-3.286 * \\
(1.895)\end{array}$ & $\begin{array}{l}-0.012 * \\
(0.043)\end{array}$ & $\begin{array}{l}-3.725^{* *} \\
(1.490)\end{array}$ & $\begin{array}{l}-0.119 \text { ** } \\
(0.059)\end{array}$ \\
\hline Intercept & $\begin{array}{l}7.891 * * * \\
(2.920)\end{array}$ & & $\begin{array}{l}3.493 \\
(5.229)\end{array}$ & & $\begin{array}{l}8.968^{* *} \\
(3.615)\end{array}$ & \\
\hline $\begin{array}{l}N \\
\text { Pseudo- } R^{2}\end{array}$ & $\begin{array}{l}133 \\
0.44\end{array}$ & & & & & \\
\hline
\end{tabular}

Note: Standard errors in parentheses. ${ }^{* * *} p<0.01,{ }^{* *} p<0.05,{ }^{*} p<0.1$. Note: The variable 'successors' gender' is not included, as all successors are male.

Farm Successors' Characteristics: Personal characteristics of the farm successor such as age and educational attainment are found to be important determinants of occupational choices. The age of the successor influences (at the $10 \%$ level of significance) the undecided category negatively. Most farm successors make their decision to continue farming or discontinue and exit within the first few years of their farm take-over. Therefore, the older the farmer, the lower the likelihood is of him being undecided. Regarding education, a higher level of schooling is significantly related to farm exits (at a $5 \%$ level of significance). The positive sign of the coefficient implies that as the educational level goes up, the probability of exiting farming occupation also increases relative to full-time farming. Concerning marital status, the marginal effects show a $14 \%$ lower tendency of exiting farming occupation 
if the farm successor is married. This can be understood by the fact that the decisions regarding switching occupations are risky. Therefore, married farm successors, due to their greater responsibilities, may hesitate to abandon their farming business. These results are in line with other studies [32,50].

Farm Characteristics: The only farm-related variable that is significantly linked with the occupational choice is the physical farm size measured in terms of total land owned. The total land owned is negatively and significantly (at a 5\% level of significance) linked with part-time farming relative to full-time farming. This can be explained, first, by the fact that most of the very large farms are operated full-time and, in an event of succession, would still require to be operated full-time. Second, of most small and medium-sized farms specialized in horticulture, many are involved in diversification activities, e.g., the processing of farm products and the offering of recreational services. Hence, the larger the farm, the lower the probability is of it being operated part-time. Furthermore, marginal effects indicate that an increase in landholding by 1 kanal decreases the likelihood of farm successors choosing part-time farming as their occupational choice by $1 \%$. These results are consistent with the findings of Coopmans et al. [51]. The authors described farm characteristics as "agricultural resources", which included access to finance, land and adequate labor.

Agricultural income is negatively associated with the choice 'part-time' and 'exit' ( $10 \%$ level of significance), implying that the farm productivity and economic health of the farm influence the future intentions of farm successors. At the same time, off-farm work and diversification activities by the main farm manager also significantly influence the decisions of farm successors. The marginal effects show that an off-farm job by the main farm operator increases the likelihood of successors' involvement in part-time farming by $12 \%$, while involvement in diversification activity decreases the likelihood of farm exit by $11 \%$ and undecidedness by $16 \%$. This indicates that farm successors on part-time farms would most likely continue to operate part-time if they do not exit. However, farm successors on farms with diversification may also continue to work part-time, but their inclination towards abandoning farms is not expected. Aldanondo Ochoa et al. [33] and Hennessy and Rehman [32] also obtained similar results.

Others: The active participation of the farm successor in farming activities understood as commitment and emotional attachment also affect the occupational choice. The variable 'on-farm participation' is significantly and negatively associated with 'part-time', 'exit' and 'undecided' choice categories. If the farm successor participates in farming activities, the probability of being undecided decreases by $12 \%$. The farm successors, through socialization (starting at an early age) and learning from their surroundings, develop their affinity towards farming, which encourages them to continue working on the farm. Chiswell [2] also reported similar results.

\section{Conclusions}

The issue of farm survival is associated with the long-term sustainability of the agriculture sector, particularly in the rural mountainous regions of developing countries. In the GB region, increased rural outmigration combined with a greater share of off-farm income at the household level and the growing disinterest of the younger population in taking over family farms is posing threats to the continuity of agricultural activity. Therefore, we studied the factors influencing the phenomenon of intergenerational farm succession in terms of the presence of farm successors and their future occupational choices.

Regarding the model estimating farm succession, our study concludes that farmers who benefit from higher agricultural income (and supplemental income from agricultural diversification) can influence their children to continue their family farm businesses. Furthermore, the main farmers' personal characteristics, such as age and agricultural expertise in terms of training attended and intention to sustain farming (measured through diversification and persistent efforts to improve farm productivity), mainly determine farm succession. Therefore, the use of participatory approaches in extension activities such 
as 'farmer field schools', training in agricultural development particularly in integrated insect pests and disease management can help the older segments of farming communities better cope with the lower productivity. Furthermore, infrastructure and land development schemes and investments in irrigation technologies (such as tunnel farming) can also enhance farming opportunities in the region. Additionally, incentivizing young farmers' involvement in agriculture through subsidies on technological advancement can also develop their interest in agricultural business activities.

The analysis of the occupational choice of farm successors indicates that successors' decisions are greatly influenced by personal and family factors. Farm successors are more likely to pursue part-time farming than to operate on a full-time basis if the main farmer is involved in an off-farm job and the successor does not participate in farming operations. Moreover, farm successors are more inclined towards exiting if they are highly educated, whereas farm diversification is found to prevent farm exits. Therefore, through youth development programs such as youth entrepreneurship in agriculture and training activties in enterprise development, the rate of employment in agriculture and the income situation can be improved. Additionally, the promotion of technological innovation and modernization in agriculture through conducting agricultural training for skill building, especially aimed at the youth, can help to retain the younger segments of the rural labor force on the farms. Our results further imply that investments in improving local farm structure and policies directed at the promotion of diversification activities can discourage farm abandonment.

This study gives useful insights into different aspects of farm succession and provides helpful policy recommendations. Nevertheless, from a policy perspective, there remains a need to conduct more research such as longitudinal studies in a broader context, including other districts of GB. Such further investigations shouldfocus on the changing patterns and trends in farm succession to offer a better understanding of the underlying key agricultural development issues.

Author Contributions: Conceptualization, M.A.S., S.A. and C.F.; investigation, M.A.S. and S.A.; project administration, M.A.S.; supervision, C.F.; writing-original draft, M.A.S. and S.A.; writingreview and editing, M.A.S. and C.F. All authors have read and agreed to the published version of the manuscript.

Funding: This work was supported by the Open Access Publishing Fund of the Free University of Bozen-Bolzano.

Institutional Review Board Statement: The study was conducted with the approval of the Directorate of Agriculture Research Gilgit-Baltistan, Government of Gilgit-Baltistan, Pakistan.

Informed Consent Statement: Informed consent was obtained from all the respondents before the survey was carried out.

Data Availability Statement: Restrictions apply to the availability of these data. Data are available from the authors with the permission of collaborators at a reasonable request.

Acknowledgments: We thank Fazal Rehman, Director at the Directorate of Agriculture Research Gilgit-Baltistan and, Mahmood Asghar, Assistant Director at the Department of Agriculture Extension Gilgit-Baltistan, Government of Gilgit-Baltistan, Pakistan for their support in data collection.

Conflicts of Interest: The authors declare no conflict of interest.

\section{References}

1. Pessotto, A.P.; Costa, C.; Schwinghamer, T.; Colle, G.; Corte, V.F.D. Factors influencing intergenerational succession in family farm businesses in Brazil. Land Use Policy 2019, 87, 104045. [CrossRef]

2. Chiswell, H.M. From Generation to Generation: Changing Dimensions of Intergenerational Farm Transfer. Sociol. Rural. 2016, 58, 104-125. [CrossRef]

3. Silva, V.R.d.; Silva, M.M.d.; Pereira, M.C.d.B. Pluriactivity and sustainability in rural communities of semiarid northeast. Desenvolv. E Meio Ambiente 2015, 35, 349-366.

4. Corsi, A. Family Farm Succession and Specific Knowledge in Italy. Riv. Di Econ. Agrar. 2009, 64, 13-30. 
5. Cavicchioli, D.; Bertoni, D.; Tesser, F.; Frisio, D.G. What Factors Encourage Intrafamily Farm Succession in Mountain Areas? Mt. Res. Dev. 2015, 35, 152. [CrossRef]

6. World Bank Gilgit-Baltistan Economic Report: Broadening the Transformation. Report No. 55998-PK. 2010. Available online: https: / / documents1.worldbank.org/curated/en/971671468057878511/pdf/559980ESW0Gray1OFFICIAL0USE0ONLY191.pdf. (accessed on 9 November 2021).

7. Rasul, G.; Hussain, A. Sustainable Food Security in the Mountains of Pakistan: Towards a Policy Framework. Ecol. Food Nutr. 2014, 54, 625-643. [CrossRef]

8. Shahzad, M.A.; Ahmed, V.; Fischer, C. Status and determinants of other gainful activities by farmers in mountainous rural regions of Gilgit-Baltistan, Pakistan. J. Mt. Sci. 2021, 18, 2520-2539. [CrossRef]

9. Gioli, G.; Khan, T.; Bisht, S.; Scheffran, J. Migration as an Adaptation Strategy and its Gendered Implications: A Case Study From the Upper Indus Basin. Mt. Res. Dev. 2014, 34, 255-265. [CrossRef]

10. Anwar, S.; Khan, F.A.; Rahman, A.-U. Impact of Karakoram Highway on Land use and Agricultural Development of GilgitBaltistan, Pakistan. Sarhad J. Agric. 2019, 35, 417-431. [CrossRef]

11. Benz, A. Framing Modernization Interventions:Reassessing the Role of Migration and Translocality in Sustainable Mountain Development in Gilgit-Baltistan, Pakistan. Mt. Res. Dev. 2016, 36, 141-152. [CrossRef]

12. Goeller, D. Facilitating Succession and Retirement in US Agriculture: The Case of Nebraska. In Keeping It in the Family: International Perspectives on Succession and Retirement on Family Farms; Ashgate Publishing Company: Farnham, UK, 2012 ; pp. 149-163.

13. Ingram, J.; Kirwan, J. Matching new entrants and retiring farmers through farm joint ventures: Insights from the Fresh Start Initiative in Cornwall, UK. Land Use Policy 2011, 28, 917-927. [CrossRef]

14. Mishra, A.K.; El-Osta, H.S.; Shaik, S. Succession Decisions in U.S. Family Farm Businesses. J. Agric. Resour. Econ. 2010, 35, 133-152.

15. Gasson, R.; Errington, A.; Tranter, R. Carry on Farming: A Study of How English Farmers Have Adapted to the Changing Pressures on Farming; Department of Agricultural Economics and Business Management, Wye College: Wye, UK, 1998 ; ISBN 0862660645.

16. Conway, S.F.; McDonagh, J.; Farrell, M.; Kinsella, A. Uncovering obstacles: The exercise of symbolic power in the complex arena of intergenerational family farm transfer. J. Rural. Stud. 2017, 54, 60-75. [CrossRef]

17. Hinojosa, L.; Napoléone, C.; Mouléry, M.; Lambin, E.F. The "mountain effect" in the abandonment of grasslands: Insights from the French Southern Alps. Agric. Ecosyst. Environ. 2016, 221, 115-124. [CrossRef]

18. Barclay, E.; Foskey, R.; Reeve, I. Farm Succession and Inheritance: Comparing Australian and International Trends; Rural Industries Research and Development Corporation: Wagga Wagga, Australia, 2007.

19. Brockhaus, R.H. Family Business Succession: Suggestions for Future Research. Fam. Bus. Rev. 2004, 17, 165-177. [CrossRef]

20. Zou, B.; Mishra, A.K.; Luo, B. Aging population, farm succession, and farmland usage: Evidence from rural China. Land Use Policy 2018, 77, 437-445. [CrossRef]

21. Matthews, A. Agri-Food Sector. In The Economy of Ireland: Policy Making in a Global Context; Bloomsbury Publishing: London, UK, 2021; p. 276.

22. Hussain, J.; Zhou, K.; Akbar, M.; Khan, M.Z.; Raza, G.; Ali, S.; Hussain, A.; Abbas, Q.; Khan, G.; Khan, M.; et al. Dependence of rural livelihoods on forest resources in Naltar Valley, a dry temperate mountainous region, Pakistan. Glob. Ecol. Conserv. 2019, 20, e00765. [CrossRef]

23. Harris, J.M.; Mishra, A.K.; Williams, R.P. The Impact of Farm Succession Decisions on the Financial Performance of the Farm. In Proceedings of the Agricultural and Applied Economics Association, Annual Meeting, Seattle, DC, USA, $12-14$ August 2012.

24. Leonard, B.; Kinsella, A.; O’Donoghue, C.; Farrell, M.; Mahon, M. Policy drivers of farm succession and inheritance. Land Use Policy 2017, 61, 147-159. [CrossRef]

25. Kimhi, A.; Nachlieli, N. Intergenerational Succession on Israeli Family Farms. J. Agric. Econ. 2001, 52, 42-58. [CrossRef]

26. Stiglbauer, A.M.; Weiss, C.R. Family and Non-Family Succession in the Upper-Austrian Farm Sector. Cah. d'Economie et de Sociol. Rural. 2000, 54, 5-26.

27. Glauben, T.; Tietje, H.; Weiss, C.R. Intergenerational Succession in Farm Households: Evidence from Upper Austria. Rev. Econ. Househ. 2004, 2, 443-462. [CrossRef]

28. Cavicchioli, D.; Bertoni, D.; Pretolani, R. Farm succession at a crossroads: The interaction among farm characteristics, labour market conditions, and gender and birth order effects. J. Rural. Stud. 2018, 61, 73-83. [CrossRef]

29. Mishra, A.K.; El-Osta, H.S. Effect of agricultural policy on succession decisions of farm households. Rev. Econ. Househ. 2008, 6, 285-307. [CrossRef]

30. Glauben, T.; Petrick, M.; Tietje, H.; Weiss, C. Probability and timing of succession or closure in family firms: A switching regression analysis of farm households in Germany. Appl. Econ. 2009, 41, 45-54. [CrossRef]

31. Inwood, S.M.; Sharp, J.S. Farm persistence and adaptation at the rural-urban interface: Succession and farm adjustment. J. Rural. Stud. 2012, 28, 107-117. [CrossRef]

32. Hennessy, T.C.; Rehman, T. An Investigation into Factors Affecting the Occupational Choices of Nominated Farm Heirs in Ireland. J. Agric. Econ. 2007, 58, 61-75. [CrossRef]

33. Ochoa, A.A.; Oliva, V.C.; Sáez, C.A. Explaining farm succession: The impact of farm location and off-farm employment opportunities. Span. J. Agric. Res. 2007, 5, 214. [CrossRef] 
34. Fischer, H.; Burton, R.J.F. Understanding Farm Succession as Socially Constructed Endogenous Cycles. Sociol. Rural. 2014, 54, 417-438. [CrossRef]

35. Morais, M.; Borges, J.A.R.; Binotto, E. Using the reasoned action approach to understand Brazilian successors' intention to take over the farm. Land Use Policy 2018, 71, 445-452. [CrossRef]

36. Sottomayor, M.; Tranter, R.; Costa, L. Likelihood of Succession and Farmers' Attitudes towards their Future Behaviour: Evidence from a Survey in Germany, the United Kingdom and Portugal. Int. J. Sociol. Agric. Food 2011, 18, 121-133. [CrossRef]

37. Nuthall, P.L.; Old, K.M. Farm owners' reluctance to embrace family succession and the implications for extension: The case of family farms in New Zealand. J. Agric. Educ. Ext. 2016, 23, 39-60. [CrossRef]

38. Kerbler, B. The influence of factors of the socio-geographical structure of mountain farms in Slovenia upon farm succession statuses and decisions. Acta Geogr. Slov. 2008, 48, 277-303. [CrossRef]

39. Bertoni, D.; Cavicchioli, D. Farm succession, occupational choice and farm adaptation at the rural-urban interface: The case of Italian horticultural farms. Land Use Policy 2016, 57, 739-748. [CrossRef]

40. Carolan, M. Lands changing hands: Experiences of succession and farm (knowledge) acquisition among first-generation, multigenerational, and aspiring farmers. Land Use Policy 2018, 79, 179-189. [CrossRef]

41. Kuehne, G. My decision to sell the family farm. Agric. Hum. Values 2013, 30, 203-213. [CrossRef]

42. Brouwer, F. (Ed.) Sustaining Agriculture and the Rural Environment: Governance, Policy, and Multifunctionality; Edward Elgar Publishing: Cheltenham, UK, 2004; ISBN 1781958033.

43. Olper, A.; Raimondi, V.; Cavicchioli, D.; Vigani, M. Do CAP payments reduce farm labour migration? A panel data analysis across EU regions. Eur. Rev. Agric. Econ. 2014, 41, 843-873. [CrossRef]

44. Kimhi, A. Differential Human Capital Investments and the Choice of Successor in Family Farms. Am. J. Agric. Econ. 1995, 77, 719-724. [CrossRef]

45. UNICEF. Multiple Indicator Cluster Survey 2016-2017 (Gilgit-Baltistan), Round 5. Available online: https:/ / microdata.worldbank. org/index.php/catalog/4140. (accessed on 9 November 2021).

46. Spies, M. Changing Food Systems and Their Resilience in the Karakoram Mountains of Northern Pakistan: A Case Study of Nagar. Mt. Res. Dev. 2018, 38, 299-310. [CrossRef]

47. Kumar, K. Conducting Key Informant Interviews in Developing Countries; Agency for International Development: Washington, DC, USA, 1989.

48. Sano, S.; Tada, S.; Yamamoto, M. Method of Household Surveys and Characteristics of Surveyed Households: Comparison Regarding Household Composition, Annual Income and Educational Attainment. Public Policy Rev. 2015, 11, 505-530.

49. Lobley, M.; Baker, J.R.; Whitehead, I. Farm Succession and Retirement: Some International Comparisons. J. Agric. Food Syst. Community Dev. 2010, 1, 49-64. [CrossRef]

50. Plana-Farran, M.; Gallizo, J. The Survival of Family Farms: Socioemotional Wealth (SEW) and Factors Affecting Intention to Continue the Business. Agriculture 2021, 11, 520. [CrossRef]

51. Coopmans, I.; Dessein, J.; Accatino, F.; Antonioli, F.; Bertolozzi-Caredio, D.; Gavrilescu, C.; Gradziuk, P.; Manevska-Tasevska, G.; Meuwissen, M.; Peneva, M.; et al. Understanding farm generational renewal and its influencing factors in Europe. J. Rural. Stud. 2021, 86, 398-409. [CrossRef] 